\title{
Variation in Rates of Spore Deposition of Fusarium circinatum, the Causal Agent of Pine Pitch Canker, Over a 12-Month-Period at Two Locations in Northern California
}

\author{
M. Garbelotto, T. Smith, and W. Schweigkofler
}

First and third authors: Department of Environmental Science, Policy, and Management, University of California, Berkeley 94720; and second author: California Department of Forestry and Fire Protection, Davis 95618.

Accepted for publication 22 August 2007.

\begin{abstract}
Garbelotto, M., Smith, T., and Schweigkofler, W. 2008. Variation of spore dispersal of Fusarium circinatum, the causal agent of pine pitch canker, over a 12-month-period at two locations in Northern California. Phytopathology 98:137-143.

Patterns of spore deposition by Fusarium circinatum, the causal agent of pine pitch canker (PPC) of Monterey pine (Pinus radiata) and other conifers, were studied between May 2003 and April 2004 at two sites in Northern California using a novel spore trapping method combined with a real-time polymerase chain reaction (PCR) approach. At each study site, two plots were sampled by placing spore traps at $100 \mathrm{~m}$ intervals along transects $600 \mathrm{~m}$ in length. The air was sampled continuously by exchang-

ing the spore traps every 2 weeks. The spore deposition rate (DR), ranged from 0 to $1.3 \times 10^{5}$ spores $\mathrm{m}^{-2}$. Spores were detected throughout the year, with higher trapping frequencies (TF) during the rainy season (November to April), than during the dry season (May to October). The detection of spores on traps at distances larger than $200 \mathrm{~m}$ from any Monterey pine, suggests at least midrange aerial dispersal. Finally, different inoculum loads were associated with trees displaying different levels of disease symptoms, suggesting infectiousness of the pathogen varies as the disease progresses. This study represents one of the first documenting continuous inoculum pressure values over an entire year for a forest pathogen, and provides important epidemiological information that will be invaluable in the development of disease progression models.
\end{abstract}

Pine pitch canker (PPC), caused by Fusarium circinatum Nirenberg O'Donnell $(=F$. subglutinans [Wollenweb and Reinking] Nelson, Toussoun, and Marasas f. sp. pini [teleomorph: Gibberella circinata Nirenberg and O'Donnell]; Hypocreales) is a destructive disease of Pinus radiata (Monterey pine) and several other pine species. Symptoms include brown flagging of twigs and branch dieback caused by resin-soaked cankers, often leading to tree death. PPC is believed to be endemic in the southeastern United States and Mexico $(15,17,19,24)$, and to have been introduced more recently into South Africa (33), Japan (4), and Chile (32). PPC was detected in California for the first time in 1986 (8), and since then is spreading in both natural habitats of Monterey pines and planted areas, causing significant ecological and economical damage. According to fossil evidence, Monterey pine was once considerably more widespread on Californian coast ranges than currently (26). At present, only three native populations of Monterey pines are found in California; native Monterey pines also grow on two small Pacific islands in Northwestern Mexico. Due to the limited size of remaining native stands, all are seriously endangered by the impact of PPC; furthermore, PPC represents a serious threat for the survival of the extensive Monterey pine plantations established in several countries around the globe.

Understanding of the epidemiology of PPC remains limited, in particular there is only very limited information on the airborne spore load of $F$. circinatum. Although spores have been found associated with several insect species in the families Scolitydae, Anobiidae, and Cercopidae $(13,16)$, the role played by putative insect vectors is unclear and mostly based on coincidental obser-

Corresponding author: M. Garbelotto; E-mail address: matteo@ nature.berkeley.edu

doi:10.1094/PHYTO-98-1-0137

(C) 2008 The American Phytopathological Society vations rather than on true experimental evidence. The presence of significant spore loads in the air may challenge the hypothesis of a generalized vectoring role played by insects, and require a better understanding of temporal and spatial patterns of spore dispersal, as well as of correlation patterns between inoculum load and severity of plant symptoms.

Dispersal of airborne inoculum (conidia) is well documented to be the key for the spread of several plant diseases, including some caused by Fusaria spp. (e.g., wheat head blight $[10,12,22,36])$. In general, active spore sampling is well established in some economically important agricultural crops for the early detection of inoculum and consequently for modeling and defense of fungal infections (e.g., the use of Burkard traps in apple orchards [7,12, 21]), but such systems have not been deployed to study the aerobiology of forest pathogens. To date, most studies on the aerobiology of forest fungi $(8,14,23,24,25,27,29$, reviewed in 11) are instead based on passive trapping methods. Using passive trapping methods, the deposition rates of forest fungi have been studied by allowing spores to land on inert surfaces including microscope slides, petri dishes, freshly-cut wood surfaces, and filter paper among many others. Once captured on trapping surfaces, spores have been counted and identified either using microscopic observation or allowing spores to germinate and produce morphologically distinct colonies $(14,23)$. In some instances, successful mating with haploid colonies previously grown on trapping surfaces has been employed to target only a specific fungus (24), and, more recently, DNA based markers have been used to identify and quantify spore loads without the need for identification or culturing $(28,29)$. Although the literature using passive spore traps in forest systems is extensive, it should be noted that such passive trapping approaches do not account for the effects of environmental and ecological disturbances on spore flow and deposition. Although active trapping methods are needed to quantify spore loads in equal volumes of air, deposition rate 
values obtained with passive trapping methods may be valuable if based on extensive and replicated measurements both in space and time. Consistent results across the landscape in fact, would indicate the observations are not affected by the variation known to be intrinsically linked to passive spore trapping methods.

In this study, we used a recently developed technique for prolonged spore trapping of $F$. circinatum (28), and continuously sampled multiple sites over the course of 12 months in a native $P$. $r a$ diata habitat in the Santa Cruz Mountains and in a planted stand in the San Francisco Golden Gate National Recreation Area, in Northern California. The use of multiple trapping spots in each of two stands for each one of the sampled forests, and the fact that trapping surfaces were continuously exposed in each trapping point for 365 days, provided us with a solid tool to analyze that portion of the airspora of $F$. circinatum undergoing deposition in the two forests.

The objectives of this study were (i) to detect and quantify deposition rates of airborne inoculum of $F$. circinatum in two forests in Northern California, (ii) to determine the effect of seasonality on spore deposition, and (iii) to study correlation of spore deposition rate with distance from a putative source and with severity of symptoms.

\section{MATERIALS AND METHODS}

Field sites. The study was conducted in four plots, two located in an artificial Monterey pine stand within the Presidio, Golden Gate National Recreation Area, San Francisco, CA (SF) and two located in a native stand at the Swanton Pacific Ranch, Santa Cruz, CA (SC). The main characteristics of the field sites are listed in Table 1. At both sites, disease symptoms were in general, low to moderate (symptoms were present on 25 to $50 \%$ of the crown of infected trees), and at each site one plot was characterized by moderate symptoms, while the other included some dead trees.

PPC symptoms in the area surrounding each spore trap were characterized as follows: S0, distance from spore trap to next Monterey pine $>50 \mathrm{~m}$ : S1, Monterey pines close $(<50 \mathrm{~m})$ to spore trap, no visible symptoms (no brown flagging and pitching): S2, few symptoms; 1 to 5 twigs showing clear symptoms (brown flagging): S3, moderate symptoms; 5 to 15 twigs showing brown flagging, but no dead twigs: S4, severe symptoms; more than 15 twigs showing brown flagging and/or dead twigs: and S5, dead tree; tree without green parts, needles (if still present) were brown. Symptomatic branches were positioned predominantly at the middle and higher portions of the trees (approximately 10 to $20 \mathrm{~m}$ above ground).

Layout of the field experiments. Spore traps (28) were placed in two plots at each site. At each site, sampling points were located at $100 \mathrm{~m}$ intervals along two orthogonal transects, each $600 \mathrm{~m}$ in length, for a total of 13 sampling points per plot. The two transects cross each other at the center point (C), an area that was selected based on the presence of several Monterey pines showing moderate to severe symptoms of PPC (S3 to S4).
Vegetation type, canopy and slope. The distance to the next Monterey pine, the vegetation type, and the slope of the surrounding area and the canopy cover were recorded for each sampling point. Canopy cover was defined as the percentage of each spore trap that was shaded by overhanging tree crowns.

Meteorological data. Data on daily rainfall, high and low temperatures, and the prevailing wind direction were obtained from the UC IPM program for the two locations San Francisco and Santa Cruz (3). Temperature data were converted to low, high, and average monthly values. The monthly precipitation values and average temperature maxima are shown in Figure 1.

Spore sampling. Sampling was done over a 12-month-period from May 2003 to April 2004. Spore traps consisting of filter


Fig. 1. Variation over time of $\mathbf{A}$, trapping frequencies (TF), and $\mathbf{B}$, deposition rates (DR) of Fusarium circinatum at two sites in Northern California determined by sampling on filter paper and a real-time polymerase chain reaction (PCR) approach. Samplings were performed biweekly from May 2004 to April 2005 in San Francisco (SF) and Santa Cruz (SC) at 26 spore traps each and combined for each month $(\mathrm{N}=52)$. Means with the same letter are not significantly different according to the multiple-comparison analysis of variance (ANOVA) with the Tukey-Kramer honestly significant difference test $(P \leq 0.05)$. Monthly rainfall and average maximum temperature values are included in $\mathbf{A}$ and $\mathbf{B}$, respectively.

TABLE 1. Physical and biological characteristics of the two field sites used for spore sampling in Northern California

\begin{tabular}{|c|c|c|}
\hline & Site I Presidio Park, San Francisco, CA & Site II Swanton Pacific Ranch, Santa Cruz, CA \\
\hline Geographic location & $37^{\circ} 79^{\prime} \mathrm{N}, 122^{\circ} 46^{\prime} \mathrm{W}$ & $37^{\circ} 04^{\prime} \mathrm{N}, 122^{\circ} 13^{\prime} \mathrm{W}$ \\
\hline Elevation & Approximately 20 to $80 \mathrm{~m}$ above sea level & Approximately 150 to $300 \mathrm{~m}$ above sea level \\
\hline Main wind direction & West & West \\
\hline Distance to the ocean & Approximately 700 to $2,000 \mathrm{~m}$ & Approximately 1,500 to $4,000 \mathrm{~m}$ \\
\hline Slope & Mainly plain & Plot A: plain $(\mathrm{S}, \mathrm{W})$ and steep hills $(\mathrm{N}, \mathrm{E})$, Plot $\mathrm{B}$ : mainly plain \\
\hline Vegetation type & $\begin{array}{l}\text { Nonnative: Monterey pine (P. radiata), } \\
\text { Monterey Cypress (Cupressus macrocarpa), } \\
\text { Bluegum Eucalyptus (Eucalyptus globules), } \\
\text { Redwood (Sequoia sempervirens) }\end{array}$ & $\begin{array}{l}\text { Native: Monterey Pine, Redwood, Douglas fir (Pseudotsuga menziesii), } \\
\text { California Bay (Umbellularia californica), Bigleaf maple } \\
\text { (Acer macrophyllum), California nutmeg (Torreya californica), } \\
\text { California buckeye (Aesculus californica), ... }\end{array}$ \\
\hline Age of Monterey Pines & $\begin{array}{l}\text { Mostly ca. } 80 \text { to } 100 \text { years (uniform, with just a few } \\
\text { younger trees) }\end{array}$ & Mixed (from 0 to approximately 100 years) \\
\hline
\end{tabular}


paper (Whatman No. 1) were placed on wooden platforms (height, $1 \mathrm{~m}$ ). To increase their trapping capacity, each filter paper was wetted with $4 \times$ TE buffer ( $40 \mathrm{mM}$ of Tris-HCl, $4 \mathrm{mM}$ EDTA; Sigma Chemical Co., St. Louis, MO). Samples were collected from the field after 2 weeks and processed in the laboratory. Spores from the filter paper were washed with $20 \mathrm{ml}$ of hot $\left(65^{\circ} \mathrm{C}\right) 4 \times \mathrm{TE}$ buffer and resuspended by vortexing (maximum speed) for $5 \mathrm{~min}$. The suspensions were spun down at $1,500 \mathrm{rpm}$ for $90 \mathrm{~min}$ to concentrate the spores. After removing of the supernatant, DNA was extracted from the pellet $(100 \mu \mathrm{l})$. To prove the efficacy of the spore harvest, $0.3 \mathrm{ml}$ of the supernatant and the filter paper were plated on Fusarium-specific (28) medium, incubated at room temperature for 2 weeks, and inspected for fungal growth. DNA extracts of the spores were amplified using real-time polymerase chain reaction (PCR). The resulting threshold cycles $(\mathrm{Ct})$ were used for quantification of the starting copy number of $F$. circinatum DNA in each reaction by interpolation with the standard curve of known DNA and spore concentrations (28). The value obtained was multiplied times 131.6 to calculate the concentration of $F$. circinatum per $\mathrm{m}^{2}$ (surface size of the filter: $0.0076 \mathrm{~m}^{2}$ ).

DNA isolation from spores. Spore suspensions $(100 \mu \mathrm{l})$ were mechanically disrupted by shaking with glass beads $(0.5 \mathrm{~mm}$, Biospec Products, Inc., Bartlesville, OK) for $30 \mathrm{~s}$. After adding $0.3 \mathrm{ml}$ of CTAB extraction buffer, the samples were subjected to three freeze-thaw cycles $\left(2 \mathrm{~min}\right.$ on dry ice, $2 \mathrm{~min}$ at $75^{\circ} \mathrm{C}$, repeated three times with the last thaw extended to $30 \mathrm{~min}$ ). DNA was extracted using $0.35 \mathrm{ml}$ of phenol-chloroform-isoamyl alcohol followed by purification using the Geneclean kit (BIO 101, Carlsbad, CA), according to instructions supplied by the manufacturer (28).

Primers for the specific detection of $\boldsymbol{F}$. circinatum. Specific primers for $F$. circinatum binding to the nuclear ribosomal intergenic spacer (IGS) region were developed by Schweigkofler et al. (28) and synthesized by Qiagen-Operon (Alameda, CA) (Table 2). The amplicon size is $360 \mathrm{bp}$. The PCR mix consisted of the following ingredients: $12 \mu \mathrm{l}$ of $\mathrm{H}_{2} \mathrm{O}, 2.5 \mu \mathrm{l}$ of PCR buffer, $1.0 \mu \mathrm{l}$ $(50 \mathrm{mM})$ of $\mathrm{MgCl}_{2}, 2.5 \mu \mathrm{l}$ of dNTP, $0.25 \mu \mathrm{l}(50 \mathrm{mM})$ of primer CIRC1A, $0.25 \mu \mathrm{l}(50 \mathrm{mM})$ of primer CIRC4A, $0.25 \mu \mathrm{l}$ of Platinium Taq-Polymerase and $6.25 \mu \mathrm{l}$ of DNA template. The cycling profile was: denaturation at $94.0^{\circ} \mathrm{C}$ for $180 \mathrm{~s}$, followed by 45 cycles of $94^{\circ} \mathrm{C}$ for $35 \mathrm{~s}, 66^{\circ} \mathrm{C}$ for $55 \mathrm{~s}, 72^{\circ} \mathrm{C}$ for $50 \mathrm{~s}$, final extension $72^{\circ} \mathrm{C}$ for $12 \mathrm{~min}$.

Determination of mating type. The mating type was determined in a multiplex real-time PCR using the primers listed according to Covert et al. (9) and Wallace and Covert (30) (Table 2) (28). The mating type primers are specific to Fusarium species closely related to $F$. circinatum (Gibberella group; 28 ).

Real-time PCR. Real-time PCR using both the CIRC1A/ CIRC4A and the mating type primers sets were carried out using the iCycler from Bio-Rad (Hercules, CA, [2]). The SYBR-Green method used Sybr-Green I (Applied Biosystems, Foster City, CA) as a fluorescent dye which intercalates specifically with dsDNA during the extension phase of the PCR. For quantification of the starting amount of template DNA, the $\mathrm{Ct}$ for each sample was calculated. The $\mathrm{Ct}$ value, which is the cycle number when the fluorescence of SYBR-Green measured is significantly different from the background level for the first time, was calculated using baseline cycles 2 to 10 . The $\mathrm{Ct}$ value is proportional to the logarithm of the initial DNA concentration. The data analysis window was set at $10 \%$ of a cycle and centered at the end of the cycle. Reaction conditions for real-time PCR: $8.0 \mu$ l of $\mathrm{H}_{2} \mathrm{O}$, $2.5 \mu \mathrm{l}$ of PCR buffer, $2.5 \mu \mathrm{l}(50 \mathrm{mM})$ of $\mathrm{MgCl}_{2}, 2.5 \mu \mathrm{l}$ of dNTP, $0.25 \mu \mathrm{l}(50 \mathrm{mM})$ of forward primer, $0.25 \mu \mathrm{l}(50 \mathrm{mM})$ of reverse primer, $1.25 \mu \mathrm{l}$ of SYBR-Green, $1.25 \mu \mathrm{l}$ of fluorescein (Bio-Rad, Hercules, CA), $0.25 \mu \mathrm{l}$ of Platinium Taq-Polymerase, and $6.25 \mu \mathrm{l}$ DNA template. Cycling parameters were as follows: $94^{\circ} \mathrm{C}$ for $180 \mathrm{~s}$, followed by 45 cycles of $94^{\circ} \mathrm{C}$ for $35 \mathrm{~s}, 66^{\circ} \mathrm{C}$ for $55 \mathrm{~s}$, $72^{\circ} \mathrm{C}$ for $50 \mathrm{~s}$, followed by a final extension at $72^{\circ} \mathrm{C}$ for $12 \mathrm{~min}$. Standard curves were calculated using DNA isolated from spore suspensions of $F$. circinatum NRRL 25331 (type strain, MAT-1) which has been grown on PDA for 4 weeks. Concentrations of $10^{5}, 10^{4}, 10^{3}$, and $10^{2}$ spores per $100 \mu \mathrm{l}$ were used. Three independent amplifications were conducted for each spore concentration. Melting curves were measured for 110 cycles of $10 \mathrm{~s}$ each, starting at $60^{\circ} \mathrm{C}$ and increasing by $0.3^{\circ} \mathrm{C}$ each cycle. The melt curve is displayed as the negative first derivative of the fluorescence versus temperature plot $(-\mathrm{d}(\mathrm{RFU}) / \mathrm{dt})$ over temperature. The iCycler software identifies the melt peaks and assigns melting temperatures from this plot (2). PCR products were subjected to gel electrophoreses by loading $5 \mu \mathrm{l}$ of each PCR product onto a $1.5 \%$ agarose gel, running for $60 \mathrm{~min}$ at $20 \mathrm{~V} / \mathrm{cm}$ and staining with Ethidium bromide prior to visualization under UV.

Statistical analyses. Spore deposition was evaluated in terms of (i) percentage of infected filter papers (trapping frequency [TF]) and (ii) number of spores per $\mathrm{m}^{2}$ per month (deposition rate [DR]). While DR provides information on the quantity of airborne spores, TF may be a more appropriate measurement when analyzing the spatial distribution of spore depositions within stands. Seasonal and site-specific values were compared using analysis of variance (ANOVA) and the Tukey's honestly significant difference (HSD) test. Pair-wise comparisons were done with the Student's $t$ test. Linear regression analyses were performed to study the correlation between DR, TF, and rainfall, average maximum, average minimum temperatures using the least square criterion, and excluding replicates for which DR or TF values were zero. Statistical analyses were performed using the software SPSS 12.0G. (SPSS Inc., Chicago, IL).

\section{RESULTS}

Spore trapping using filter paper. Filter paper (Whatman no. 1) was stable for 2 weeks in the field without showing physical degradation during the dry season (May to October). Out of 624 filter papers, $617(98.9 \%)$ could be used for spore isolation; the seven missing filter papers $(1.1 \%)$ were presumably removed by strollers in the Presidio National Park (SF). During the rainy season (November to April) 30 filter papers (4.8\%) could not be analyzed due to physical damage. One spore trap (Site II-AN3) was crushed by a falling tree in March 2004 and had to be replaced. More physical damage of sampling traps was observed in SC (4.0\%), than in SF (1.9\%), especially in the more densely forested areas.

TABLE 2. Primers used for specific detection of Fusarium circinatum and determination of the mating type

\begin{tabular}{|c|c|c|c|}
\hline Primer & Sequence & Target sequence & Reference \\
\hline \multicolumn{4}{|c|}{ F. circinatum detection } \\
\hline CIRC1A & 5'CTTGGCTCGAGAAGGG & IGS forward & 21 \\
\hline CIRC4A & 5'ACCTACCCТАСАССТСТСАСТ & IGS reverse & 21 \\
\hline \multicolumn{4}{|l|}{ Mating type } \\
\hline GcHMG1 & 5'CTTTACCGTAAGGAGCGTCACCAT & MAT-2 & 8 \\
\hline GcHMG2 & 5'TGATCCGCCATCTGCTTGTAGAGT & MAT-2 & 8 \\
\hline MAT1p2 & 5'AGAAACTGACTGATACATCAAGGGG & MAT-1 & 23 \\
\hline MAT1p3 & 5'TCATAAGAAGTGTTGAAGGAATCACAG & MAT-1 & 23 \\
\hline
\end{tabular}


Detection of $F$. circinatum spores and deposition rates (DR) measured using real-time PCR. Airborne inoculum of $F$. circinatum was detected at both sites in all four plots (Table 3). The trapping frequency (TF) over the 12-month period for any given spore trap varied between 0 and $47.8 \%$. No Fusarium DNA was detected on 7 out of 52 spore traps (13.5\%), at the remaining 45 points, 1 to 11 positive samples were detected, corresponding to a TF of 4.2 and $47.8 \%$, respectively. In general, higher TF values were found in San Francisco (17.5\%, N:108) than in Santa Cruz $(11.2 \%, \mathrm{~N}: 58)(P<0.05)$. Monthly TF values are shown in Figure 1A. $\mathrm{Ct}$ of positive samples are listed in Table 3 . Single $\mathrm{Ct}$ values were in the range from 24.4 (February, SC-A plot) to 38.2 (June, SC-B plot), with most Ct values between approximately 27 and 32 (Table 3), which corresponds to a spore difference of approximately two orders of magnitude (28). Deposition rates per month for each plot (derived from the calibration curve of $\mathrm{Ct}$ against spores) are shown in Figure 1B. Average DR values were 108 spores $/ \mathrm{m}^{2} \times 10^{3}(\mathrm{SD}=232)$ for $\mathrm{SF}$ and 23 spores $/ \mathrm{m}^{2} \times 10^{3}(\mathrm{SD}=$ $29)$ for SC. Statistical analyses indicated that the difference between the two was significant at $P=0.07$; the moderate statistical significance of this comparative analysis was due to the high SD values of this data set.

Mating type. The mating type was determined from all samples which were positive using the CIRC1A-CIRC4A primers. All samples belonged to mating type MAT-1. Comparison of the Ct values using the $F$. circinatum specific primers (multi-copy target gene) versus the Gibberella group-specific primers (single copy target gene) did not give an indication for the presence of closely related Fusaria beside F. circinatum in the spore traps (data not shown).
Seasonality. Trapping frequencies (TF) and deposition rates (DR) at the four plots were measured for each month separately (Fig. 1). Monthly precipitation rates vary considerably on the California coast (Fig. 1A), with the bulk of rain falling between late October/early November and late March/early April. TF at both sites showed significant variation over time, and some of the monthly differences were significant (Fig. 1A) (HSD test, $P<$ $0.05)$.

At both sites, trapping frequency was higher during the wet season than the dry season $(31$ and $10 \%$ in San Francisco, $(P=$ $0.01)$, and 15 and $6 \%$ at Santa Cruz $(P=0.01)$. These seasonal differences occurred despite two exceptional sampling months. In San Francisco in the dry season when TF values ranged between 0 and 5\%, TF was high in August (16\%), even in the absence of rain. In Santa Cruz in the wet season, no spores were trapped in January, despite the presence of substantial rainfall $(85 \mathrm{~mm})$.

Regression analyses for DR and TF against meteorological data gave similar results, and only those obtained with TF are presented here. TF values were positively correlated with increasing rainfall, and negatively correlated with average maximum temperature in both forests (Fig. 2). Regression analyses also indicated that $\mathrm{TF}$ values were negatively correlated with average minimum temperatures, but $P$ values were not always significant, ranging between 0.04 and 0.17 for SF and SC, respectively.

Other factors. Although the $\mathrm{TF}$ of $F$. circinatum aerial spores was highest $(25.8 \%)$ at the four putative sources of inoculum, there were no significant differences in spore numbers trapped at greater distances from them (TF averaged 12.75, 10.75, and 13.00 at distances of 100, 200, and $300 \mathrm{~m}$, respectively; $P=0.268)$.

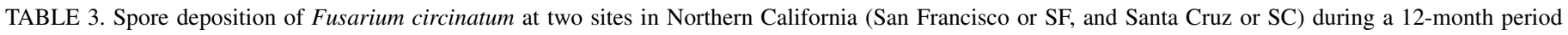
(May 2003 to April 2004) $)^{\mathrm{a}}$

\begin{tabular}{|c|c|c|c|c|c|c|c|c|c|c|c|c|}
\hline \multirow[b]{2}{*}{ Position } & \multicolumn{4}{|c|}{ SC Plot A } & \multicolumn{4}{|c|}{ SC Plot B } & \multicolumn{2}{|c|}{ SC Plot A+B } & \multicolumn{2}{|c|}{$\mathrm{SC}+\mathrm{SF}$} \\
\hline & $\mathrm{N}(\%)$ & $\mathrm{TF}$ & $\mathrm{Ct}$ & $\begin{array}{c}\text { DR (spores/ } \\
\left.\mathrm{m}^{2} \times 10^{3}\right)\end{array}$ & $\mathrm{N}(\%)$ & $\mathrm{TF}$ & $\mathrm{Ct}$ & $\begin{array}{c}\text { DR (spores/ } \\
\left.\mathrm{m}^{2} \times 10^{3}\right)\end{array}$ & $\mathrm{N}(\%)$ & $\mathrm{TF}(\%)$ & $\mathrm{N}(\%)$ & $\mathrm{TF}$ \\
\hline $\mathrm{C}$ & 8 & 33.3 & 28.9 & 105.3 & 4 & 16.7 & 30.1 & 52.6 & 12 & 25.0 & 24 & 25.8 \\
\hline W1 & 7 & 31.8 & 29.7 & 92.1 & 3 & 13.0 & 28.9 & 39.5 & 10 & 22.2 & 16 & 17.4 \\
\hline $\mathrm{W} 2$ & 5 & 21.7 & 29.3 & 65.8 & 2 & 8.7 & 31.8 & 2.6 & 7 & 15.2 & 16 & 17.0 \\
\hline W3 & 0 & 0.0 & 0.0 & 0.0 & 3 & 12.5 & 33.9 & 3.9 & 3 & 6.4 & 18 & 18.9 \\
\hline $\mathrm{S} 1$ & 2 & 9.1 & 30.6 & 26.3 & 0 & 0.0 & 0.0 & 0.0 & 2 & 4.3 & 5 & 5.3 \\
\hline $\mathrm{S} 2$ & 3 & 12.5 & 30.2 & 39.5 & 0 & 0.0 & 0.0 & 0.0 & 3 & 6.3 & 5 & 5.2 \\
\hline $\mathrm{S} 3$ & 2 & 8.3 & 32.1 & 2.6 & 3 & 13.0 & 33.6 & 3.9 & 5 & 10.6 & 7 & 7.4 \\
\hline E1 & 1 & 4.3 & 30.3 & 13.2 & 1 & 4.4 & 29.7 & 13.2 & 2 & 4.3 & 9 & 10.0 \\
\hline E2 & 2 & 10.0 & 31.2 & 2.6 & 2 & 8.4 & 29.0 & 26.4 & 4 & 9.1 & 9 & 9.8 \\
\hline E3 & 1 & 4.2 & 30.2 & 13.2 & 1 & 4.2 & 28.5 & 13.2 & 2 & 4.3 & 16 & 17.0 \\
\hline N1 & 2 & 8.7 & 30.8 & 26.3 & 1 & 4.2 & 31.8 & 1.3 & 3 & 6.4 & 20 & 21.5 \\
\hline $\mathrm{N} 2$ & 0 & 0.0 & 0.0 & 0.0 & 1 & 4.2 & 29.2 & 1.3 & 1 & 2.2 & 11 & 11.8 \\
\hline N3 & 4 & 20.0 & 30.4 & 52.6 & 0 & 0.0 & 0.0 & 0.0 & 4 & 9.3 & 10 & 11.1 \\
\hline \multirow[t]{2}{*}{$\sum$} & 37 & 12.7 & & & 21 & 6.8 & & & 58 & 11.2 & 166 & 13.7 \\
\hline & \multicolumn{4}{|c|}{ SF Plot A } & \multicolumn{4}{|c|}{ SF Plot B } & \multicolumn{2}{|c|}{ SF Plot A+B } & & \\
\hline Position & $\mathrm{N}(\%)$ & $\mathrm{TF}$ & $\mathrm{Ct}$ & $\begin{array}{c}\text { DR (spores/ } \\
\left.\mathrm{m}^{2} \times 10^{3}\right)\end{array}$ & $\mathrm{N}(\%)$ & $\mathrm{TF}$ & $\mathrm{Ct}$ & $\begin{array}{c}\text { DR (spores/ } \\
\left.\mathrm{m}^{2} \times 10^{3}\right)\end{array}$ & $\mathrm{N}(\%)$ & $\mathrm{TF}$ & & \\
\hline $\mathrm{C}$ & 5 & 22.7 & 27.2 & 658.0 & 7 & 30.4 & 28.0 & 92.1 & 12 & 26.7 & & \\
\hline W1 & 1 & 4.2 & 32.4 & 1.3 & 5 & 21.7 & 29.5 & 65.8 & 6 & 12.8 & & \\
\hline $\mathrm{W} 2$ & 0 & 0.0 & 0.0 & 0.0 & 9 & 37.5 & 29.4 & 118.4 & 9 & 18.8 & & \\
\hline W3 & 5 & 20.8 & 30.2 & 65.8 & 10 & 41.7 & 29.6 & 131.6 & 15 & 31.3 & & \\
\hline $\mathrm{S} 1$ & 1 & 4.2 & 29.9 & 13.2 & 2 & 8.3 & 29.4 & 26.3 & 3 & 6.3 & & \\
\hline $\mathrm{S} 2$ & 0 & 0.0 & 0.0 & 0.0 & 2 & 8.3 & 32.5 & 2.6 & 2 & 4.2 & & \\
\hline S3 & 1 & 4.2 & 28.4 & 13.2 & 1 & 4.2 & 32.3 & 2.6 & 2 & 4.2 & & \\
\hline E1 & 1 & 4.2 & 29.7 & 13.2 & 6 & 30.0 & 29.1 & 79.0 & 7 & 15.9 & & \\
\hline $\mathrm{E} 2$ & 2 & 8.4 & 30.8 & 26.3 & 3 & 12.5 & 31.8 & 3.9 & 5 & 10.4 & & \\
\hline E3 & 3 & 12.5 & 32.2 & 39.5 & 11 & 47.8 & 27.7 & 144.8 & 14 & 29.8 & & \\
\hline N1 & 9 & 37.5 & 27.7 & 118.4 & 8 & 36.4 & 27.2 & $1,052.8$ & 17 & 37.0 & & \\
\hline N2 & 1 & 4.2 & 32.9 & 1.3 & 9 & 37.5 & 28.5 & 118.4 & 10 & 20.8 & & \\
\hline N3 & 1 & 4.4 & 29.1 & 13.2 & 5 & 20.8 & 31.7 & 6.6 & 6 & 12.8 & & \\
\hline$\sum$ & 30 & 9.7 & & & 78 & 25.7 & & & 108 & 17.5 & & \\
\hline
\end{tabular}

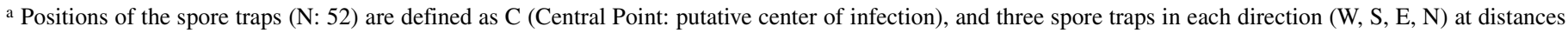
of 100, 200, and $300 \mathrm{~m}$ to C. Trapping frequencies (TF) were calculated as percentage of infected filter papers, which were collected twice a month (N: 24 per position). Deposition rates (DR) on a given position were calculated using real-time PCR (Ct: average threshold cycle per spore trap). 
High TF (48\%) and DR (145 spores $\left./ \mathrm{m}^{2} \times 10^{3}\right)$ values were recorded in one trap (site I-BE3) located more than $200 \mathrm{~m}$ from any Monterey pine.

There was also no significant effect of wind direction on TF. The main wind direction in all four plots is from the West, and TF on the four West-East transects did not show any significant difference between traps to the east of the putative source of inoculum and those to the west $(P=0.450)$. There was no significant difference between TF in spore traps in "open meadows" (with no adjacent trees or shrubs), and traps where the trap surface was close to a tress canopy (average values for TF were 3.0 and 3.3 , respectively, for traps with and without canopy $P=$ $0.440)$.

\section{DISCUSSION}

Quantitative analyses of airborne inoculum over an extended period of time are essential for epidemiological studies, but still not common in forest pathology $(18,28,29)$. Because of the intrinsic difficulty of obtaining objective measurements of spore density in the air in a forest setting, we developed a method that would enable us to evaluate spore deposition rates at a significant number of points per study site, continuously for an entire year. In this study, we present the first continuous long-term measurement of spore deposition rates of F. circinatum, the causal agent of PPC in the field.

By sampling a total of 52 points, we were able to test the influence of a variety of geographical, vegetational, and climatic parameters on TF and DR. The stability of the filter papers in the field was sufficient to allow for prolonged sampling (1 year at 2week intervals). Data from this study show that the sampling assay used here was not affected by the amount of canopy cover at the sampling points, hence the method proved itself to be robust enough to compare deposition rate values at varying distances from known sources of inoculum across the landscape, independent of cover. All inferences made here are based on replicated data (multiple trapping points) and using cumulative values of spore loads deposited on the traps in the course of a month. We believe that such spatial and temporal replication allows for robust conclusions on the differences in deposition rates recorded in the course of the study. For instance, conclusions regarding temporal fluctuations in overall infection frequency and deposition rate values are based on data from all 52 trapping points.

Regression analyses highlighted a significant negative correlation between temperature and $\mathrm{TF}$, and a positive correlation between rainfall and TF. It should be noted that the two variables, rainfall and temperature, expectedly are not independent, and that at the study sites a strong correlation was recorded between cooler temperatures and higher rainfall (e.g., for San Francisco, negative correlation between maximum temperature and rainfall had $P=0.0006$, and $R^{2}=0.71$ ). In line with the regression results, higher spore counts, both in terms of frequency and cumulative deposition rates, were detected during the cool rainy season (November to April). This finding is in agreement with the requirement for elevated moisture for spore production of Fusarium species $(12,35)$ and most plant pathogens. An analysis of temperature and precipitation charts for Northern California in 2003 to 2004 pointed to a clear demarcation between a cool rainy season (November to March) and a warm dry season (April to October) (Fig. 1).

The lack of any spore deposition in Santa Cruz in January, in spite of abundant rainfall, indicated the presence of a limiting factor other than moisture levels. A close observation of climatic data charts showed no significant differences between the sites in precipitation, high or average temperatures, but identified significant differences in low temperature values $(P<0.001)$. The average monthly low temperature values were $4.4^{\circ} \mathrm{C}(\mathrm{SD}=4.9)$ and $7.0^{\circ} \mathrm{C}(\mathrm{SD}=2.9)$ for Santa Cruz and San Francisco, respectively. In Santa Cruz, 12 days in January recorded daily low temperatures below $4.4^{\circ} \mathrm{C}$, while in San Francisco there were only 3 days with low temperatures below $4.4^{\circ} \mathrm{C}$.

Furthermore, regression analyses between TF and average minimum temperatures were not significant $(P=0.17)$ for Santa Cruz, suggesting that the inverse relationship detected between maximum temperatures and TF, may not apply when temperatures approach $0^{\circ} \mathrm{C}$. On the coast of Central California, rarely do average maximum temperatures go below $10^{\circ} \mathrm{C}$, but as recorded during our study, minimum temperatures are more likely to reach values around $0^{\circ} \mathrm{C}$ in the region. We suggest a threshold effect, noticeable when minimum temperatures approach the zero (i.e., while sporulation may be favored by wet and cool conditions, as indicated by results of regression analyses between average maximum temperature and TF values, it may actually be inhibited if it gets too cold). Another notable exception to the general pattern of sporulation here described is represented by the high TF values recorded in San Francisco in August, in the absence of any rainfall. We suggest this unusual sporulation level may have been linked to the presence of persistent oceanic fog at the study site during that month. Because oceanic fog is one of the most common characteristics of the climate along the coast of California, summer sporulation may be frequent in conjunction with months characterized by heavy fog.

Our data thus indicated that sporulation (i) is enhanced during cool-wet conditions, (ii) does not occur in cold-wet conditions when average minimum temperatures approach the zero, and (iii) may occur in warm conditions in the absence of rainfall if high humidity is caused by coastal fog. These observations may have significant implication in the prediction of the spread of the disease in Northern California and suggests PPC disease epidemics may occur in areas with mild wet winters or wet summers. Seasonal variations in levels of deposition rates of $F$. circinatum have been previously reported $(8,28)$. The data from the current study matches the preliminary data presented in Schweigkofler et al. (28), considering that both studies used the same sampling approach and were performed at similar sites in the San Francisco Bay area, the two data sets combined provide solid evidence on the seasonal, weather-induced variations in spore deposition rates of this pathogen. The reason why TF and DR values were often significantly higher in SF is not clear: because PPC has arrived at that site more recently, it may still be in exponential phase of spread at that location. Alternatively or additionally, the fact that
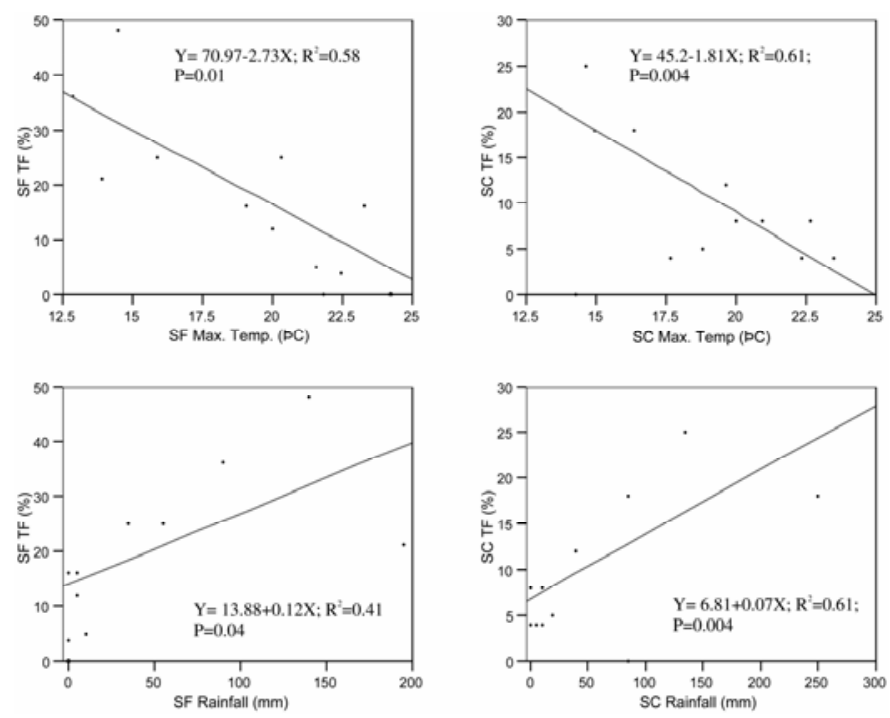

Fig. 2. Regression analyses showing the correlation of trapping frequency (TF) by Fusarium circinatum spores with rainfall and maximum temperature both in San Francisco (SF) and Santa Cruz (SC). 
the site at $\mathrm{SC}$ was located in a native $P$. radiata stand, may indicate that native stands are more resilient to infection by this pathogen, as suggested elsewhere (16). Finally, mesoclimatic environmental conditions and forest stand characteristics not identified in this study may differently influence disease progression at the two sites.

Our data indicated that spore densities were extremely variable among sampling points, suggesting a strong local effect on spore deposition rates, and reinforcing the need for inferences to be based on values averaged across multiple trapping points. Traps placed near trees judged by us as displaying intermediate symptoms, were characterized by DR values higher than those near trees displaying either low or high intensity of symptoms. These results support an epidemiological pattern of infectivity levels at first increasing, as the disease takes over the host, and then decreasing, when the host, in its final stages of disease, becomes less than optimal to support sporulation of the pathogen.

Because our plots were centered in the vicinity of moderately symptomatic trees, deposition rates were higher at the center of our plots than along transects. High aerial concentration of spores of plant-pathogenic fungi at the source of inoculum is well documented $(5,6,21)$, but the estimated dispersal distances vary considerably. The detection of high concentrations of spores hundreds of meters from any known host plant $(P$. radiata) indicated the presence of wind dispersal over at least midrange distances (several $100 \mathrm{~m}$ ). Once in a strong air stream, movement of some fungal spores can reach up to $1,000 \mathrm{~km}$ and more. For instance, windborne spores of Cronartium ribicola, the cause of white pine blister rust, have been found up to a distance of 1,300 km from the next known source of inoculum (34). Although our study was not designed to test for long-distance dispersal, the retrieval of spores hundreds of meters away from any inoculum source appears to be in striking contrast with the limited dispersal ability of rain splash fungi and of fungi that sporulate on the ground such as Venturia inaequalis, Botryosphaeria dothidea, and even some Fusarium spp. (e.g., F. culmorum and F. poae) $(1,20,21,22)$. Although we were not able to detect a significant correlation between prevailing wind direction and inoculum load, our results were probably inconclusive because of the high level of background inoculum at our study sites. Different approaches including active sampling methods and shorter sampling times are needed to investigate the role played by wind and to fully elucidate the inoculum dilution patterns of this pathogen.

F. circinatum is heterothallic and has a sexual stage in Gibberella circinata, but only little is known about the role of the teleomorph for the epidemiology of PPC. Asexual propagation of $F$. circinatum via conidia seems to be prevalent in the study areas, as indicated by the fact that only mating type MAT-1 was detected.

Despite considerable concern about the environmental and economic impact of PPC, relatively little is known about natural dispersal of the causal pathogen and the infection process. Several insects native to California, especially twig beetles belonging to the genus Pityophthorus (Coleoptera: Scolytidae) have been shown to carry $F$. circinatum (16). One to several generations of beetles are produced each year in California, depending on species, elevation, and latitude (34). Pityophthorus spp., induce wounds on Monterey pines, which could act as infection sites for the high numbers of airborne $F$. circinatum spores found in California forests as documented in this study. Clear evidence pointing to a strict vectoring role played by this and other insects is currently missing. Comparative studies on inoculum loads carried by insects versus inoculum loads in the air are needed to assess the relative importance of either putative sources of infection.

In summary, the detection of a single mating type at the study sites implies pathogen dispersal occurs via conidia rather than sexually produced ascospores, shows higher spore deposition rates in conjunction with cool-wet periods, indicates no spores are deposited when low temperatures reach freezing values, links higher infectious stages with intermediate host symptoms, and shows airborne conidia can travel at least a few hundred meters The results presented here may be useful to model patterns of spread of $F$. circinatum on the West Coast of North America and elsewhere, and to predict fluctuations in populations of the pathogen dependent on weather patterns and on symptoms of host trees.

\section{ACKNOWLEDGMENTS}

We thank the Presidio Trust, San Francisco CA, and the California Polytechnic State University, San Luis Obispo CA, for the use of the field sites and logistic support. W. Mark and C. Conforti were crucial for the implementation of the field study. For technical assistance, we thank D. Schmidt, A. Smith, K. Maeda, K. Peay, and Y. Yao from the University of California, Berkeley. This research was supported by the State of California Department of Forestry and Fire Protection (grant 8CA99067).

\section{LITERATURE CITED}

1. Ahimera, N., Gisler, S., Morgan, D. P., and Michailides, T. J. 2004. Effects of single-drop impactions and natural and simulated rains on the dispersal of Botryosphaeria dothidea conidia. Phytopathology 94:11891197.

2. Anonymous. 2001. Page 118 in: The iCycler iQ Real-Time Detection System Resource Guide. Bio-Rad, Hercules, CA.

3. Anonymous. UC IPM online. Statewide Integrated Pest Management Program. http://www.ipm.ucdavis.edu:/calludt.cgi/WXDATAREPORT.

4. Aoki, T., O'Donnell, K., and Ichikawa, K. 2001. Fusarium fractiflexum sp. nov. and two other species within the Gibberella fujikuroi species complex recently discovered in Japan that form aerial conidia in false heads. Mycoscience 42:461-478.

5. Aylor, D. E. 1995. Vertical variation of aerial concentration of Venturia inaequalis ascospores in an apple orchard. Phytopathology 85:175-181.

6. Aylor, D. E. 1999. Biophysical scaling and the passive dispersal of fungus spores: Relationship to integrated pest management strategies. Agric. For. Meteorol. 63:133-147.

7. Aylor, D. E., Fry, W. E., Mayton, H., and Andrade-Pieota, J. L. 2001.Quantifying the rate of release and escape of $P$. infestans sporangia from a potato canopy. Phytopathology 91:1189-1196.

8. Correll, J. C., Gordon, T. R., McCain, A. H., Fox, J. W., Koehler, C. S., Wood, D. L., and Schultz, M. E. 1991. Pitch canker disease in California: Pathogenicity, distribution and canker development on Monterey pine (Pinus radiata). Plant Dis. 75:676-682.

9. Covert, S. F., Briley, A., Wallace, M. M., and McKinney, V. T. 1999. Partial MAT-2 gene structure and the influence of temperature on mating success in Gibberella circinata. Fungal Genet. Biol. 28:43-45.

10. De Matos, A. P., Sanches, N. F., and Costa, J. L. D. 1997. Patterns of diurnal and seasonal airborne spore concentrations of Fusarium subglutinans in a pineapple orchard in Brazil. Acta Hort. (ISHS) 425:515524.

11. Edmon, M., Gustafsson, M., Stenlid, J., Jonsson, B. J., and Ericsson, L. 2004. Spore deposition of wood decay fungi: Importance of landscape composition. Ecography 27:103-111.

12. Fernando, W. G. D., Miller, J. D., Seaman, W. L., Seifert, K., and Paulitz, T. C. 2000. Daily and seasonal dynamics of airborne spores of Fusarium graminearum and other Fusarium species sampled over wheat plots. Can. J. Bot. 78:497-505.

13. Fox, J. W., Wood, D. L., Koehler, C. S., and O'Keefe, S. T. 1991. Engraver beetles (Scolytidae: Ips species) as vectors of the pitch canker fungus, Fusarium subglutinans. Can. Entomol. 123:1355-1367.

14. Gonthier, P., Garbelotto, M., and Nicolotti, G. 2005. Seasonal patterns of spore deposition of Heterobasidion species in four forests of the Western Alps. Phytopathology 95:759-767.

15. Gordon, T. R., Storer, A. J., and Okamoto, D. 1996. Population structure of the pitch canker pathogen Fusarium subglutinans f. sp. pini in California. Mycol. Res. 100:850-854.

16. Gordon, T. R., Storer, A. J., and Wood, D. L. 2001. The pitch canker epidemic in California. Plant Dis. 85:1128-1139.

17. Guerra-Santos, J. 1988. Pitch Canker on Monterey Pine in Mexico.Pages 58-61 in: Current and Potential Impacts of Pitch Canker in Radiata Pine. M. Devey, C. Matheson, and T. R. Gordon, eds. Proc. IMPACT Monterey Workshop, CSIRO, Collingwood, Victoria, Australia.

18. Hayden, K.J., Rizzo, D., Tse, J., and Garbelotto, M. 2004. Detection and quantification of Phytophthora ramorum from California forests using a real-time polymerase chain reaction assay. Phytopathology 94:1075-1083.

19. Hepting, G. H., and Roth, E. R. 1946. Pitch canker, a new disease of some southern pines. J. For. 44:742-744. 
20. Hirst, J. M., and Stedman, O. J. 1962. The epidemiology of apple scab (Venturia inaequalis [Cke.9 Wint.): III. The supply of ascospores. Ann. Appl. Biol. 50:551-567.

21. Holb, I. J., Heijne, B., Withagen, J. C. M., and Jeger, M. J. 2004. Dispersal of Venturia inaequalis ascospores and disease gradients from a defined inoculum source. J. Phytopathol. 152:639-646.

22. Hörberg, H. M. 2002. Patterns of splash dispersed conidia of Fusarium poae and Fusarium culmorum. Eur. J. Plant Pathol. 108:73-80.

23. James, R. L., and Cobb, F. W. 1984. Spore deposition by Heterobasidion annosum in forests of California. Plant Dis. 246-248.

24. James, T., and Vilgalys, R. 2001. Abundance and diversity of Schizophyllum commune spore clouds in the Caribbean detected by selective sampling. Mol. Ecol. 10:471-479.

25. Kallio, T. 1970. Aerial distribution of the root-rot fungus Fomes annosus (Fr.) Cooke in Finland. Acta For. Fennica 107:1-55.

26. Ornduff, R., Faber, P. M., and Keeler-Wolf, T. 2003. Introduction to California plant life. University of California Press, Berkeley, CA.

27. Rishbeth, J. 1959. Dispersal of Fomes annosus Fr. and Peniophora gigantea (Fr.) Massee. Trans. Br. Mycol. Soc. 42:243-260.

28. Schweigkofler, W., O'Donnell, K., and Garbelotto, M. 2004. Detection and quantification of airborne conidia of Fusarium circinatum, the causal agent of pine pitch canker, from two California sites using a real-time PCR approach combined with a simple spore trapping method. Appl. Env. Microbiol. 70:3512-3520.

29. Schweigkofler, W., Otrosina, W. J., Smith, S. L., Cluck, D. R., Maeda, M., Peay, K. G., and Garbelotto, M. 2005. Detection and quantification of
Leptographium wageneri, the cause of black-stain root disease, from bark beetles (Coleoptera: Scolytidae) in Northern California using regular and real-time PCR. Can. J. For. Res. 35:1798-1808.

30. Wallace, M. M., and Covert, S. F. 2000. Molecular mating type assay for Fusarium circinatum. Appl. Environ. Microbiol. 66:5506-5508.

31. Wikler, K. R. 1999. Tracing the course of an introduced pathogen: Population biology of the causal agent of pitch canker, Fusarium circinatum, and epidemiology of pitch canker disease in a native stand of Pinus radiata. Ph.D. diss. University of California, Berkeley.

32. Wingfield, M. J., Jacobs, A., Coutinho, T. A., Ahumada, R., and Wingfield, B. D. 2002. First report of the pitch canker fungus, Fusarium circinatum, on pines in Chile. New Dis. Rep., vol. 4. Published online. http://www.bspp.org.uk/ndr/jan2002/2001-53.htm.

33. Wingfield, M. J., Wingfield, B. D., Coutinho, T. A., Viljoen, A., Britz, H., and Steenkamp, E. 1998. Pitch canker: A South African Perspective. Pages 62-69 in: Current and Potential Impacts of Pitch Canker in Radiata Pine. M. Devey, C. Matheson, and T. R. Gordon eds. Proc. IMPACT Monterey Workshop, CSIRO, Collingwood, Victoria, Australia.

34. Wood, D. L., Koerber, T. W., Scharpf, R. F., and Storer, A. J. 2003. Pests of the native California conifers. University of California Press, Berkeley, CA.

35. Xu, X. 2003. Effects of environmental conditions on the development of Fusarium ear blight. Eur. J. Plant Pathol. 109:683-689.

36. Zhang, J. X., Fernando, W. G. D., and Xue, A. G. 2005. Daily and seasonal spore dispersal by Mycosphaerella pinodes and development of Mycosphaerella blight of field pea. Can. J. Bot. 83:302-310. 